\title{
MERCURY AFFECTS AQUAPORINS ACTIVITY AND GERMINATION OF THE EMBRYONIC AXIS OF Schizolobium parahyba (Vell.) BLAKE (Fabaceae)
}

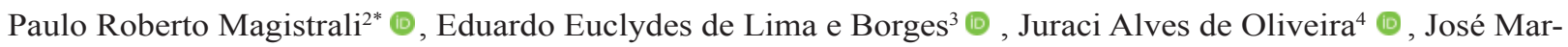

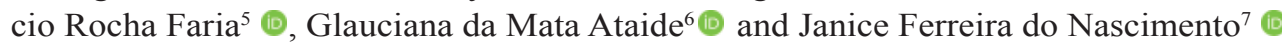

\footnotetext{
${ }^{1}$ Received on 16.09.2018 accepted for publication on 06.09.2019.

${ }^{2}$ Universidade Federal de Viçosa, Doutorado em Ciência Florestal, Viçosa, MG - Brasil. E-mail: <paulo.magistrali@ifro.edu.br>.

${ }^{3}$ Universidade Federal de Viçosa, Departamento de Engenharia Florestal, Viçosa, MG - Brasil. E-mail: <elborges@ufv.br>.

${ }^{4}$ Universidade Federal de Viçosa, Departamento de Biologia Geral, Viçosa, MG - Brasil. E-mail: <jalves@ufv.br>.

${ }^{5}$ Universidade Federal de Lavras, Departamento de Ciências Florestais, Lavras, MG - Brasil. E-mail: <jmfaria@ufla.br>.

${ }^{6}$ Universidade Federal de São João Del-Rei, Departamento Engenharia Florestal, Sete Lagoas, MG - Brasil. E-mail: <glauciana@ufsj. edu.br>.

${ }^{7}$ Instituto Federal de Educação Ciência e Tecnologia de Rondônia, Ji-Paraná, RO - Brasil. E-mail: <janice.nascimento@ifro.edu.br>.

*Corresponding author.
}

\begin{abstract}
Germination is a physiological process that begins with hydration. Specific channels known as aquaporins are responsible for water uptake through biological cell membranes. The mercuric chloride $\left(\mathrm{HgCl}_{2}\right)$ reversibly inhibits water transport during germination through the aquaporins and can changes deoxyribonucleic acid (DNA) integrity, which can result in aquaporins deficiency. The aim of this study was to evaluate the effect of $\mathrm{HgCl}_{2}$ and dithiothreitol (DTT) on aquaporins activity and on the integrity/degradation of DNA in embryonic axes of Schizolobium parahyba (Vell.) Blake during the germination process. Isolated axes were exposed to different concentrations of $\mathrm{HgCl}_{2}$ or DTT; and aquaporins activity, embryo hydration, and DNA integrity were evaluated during embryonic axes imbibition. Growth and changes in axis fresh weight were quantified. We found that the heavy metal affects seed hydration by inhibition of aquaporins activity and does not cause changes in DNA integrity.
\end{abstract}

Keywords: Aquaporins; Heavy metal; Forest seed

\section{EFEITO DO MERCÚRIO NA ATIVIDADE DE AQUAPORINAS NA GERMINAÇÃO DO EIXO EMBRIONÁRIO DE Schizolobium parahyba (Vell.) BLAKE (Fabaceae)}

\begin{abstract}
RESUMO - A germinação é um processo fisiológico que começa com a hidratação. Canais específicos conhecidos como aquaporinas são responsáveis pela absorção de água através das membranas celulares biológicas. O cloreto mercúrico $\left(\mathrm{HgCl}_{2}\right)$ inibe reversivelmente o transporte de água pelas aquaporinas durante a germinação e pode alterar a integridade do ácido desoxirribonucleico (DNA), o que pode resultar na deficiencia das aquaporinas. O objetivo deste estudo foi avaliar o efeito de $\mathrm{HgCl}$, e ditiotreitol (DTT) sobre a atividade das aquaporinas e sobre a integridadeldegradação do (DNA) em eixos embrionários de Schizolobium parahyba (Vell.) Blake durante o processo de germinação. Os eixos isolados foram expostos a diferentes concentrações de $\mathrm{HgCl}$, ou DTT; e a atividade de aquaporinas, hidratação do embrião e a integridade do DNA foram avaliadas durante a embebição do eixo embrionário. O crescimento e as mudanças no peso fresco do eixo foram quantificados. Descobrimos que o metal pesado afeta a hidratação das sementes por inibição da atividade das aquaporinas e não causa mudanças na integridade do DNA.
\end{abstract}

Palavras-Chave: Aquaporinas; Metal pesado; Sementes florestais.

Silf $(\boldsymbol{C})$ EY
Revista Árvore 2019;43(6):e430601 http://dx.doi.org/10.1590/1806-90882019000600001 


\section{INTRODUCTION}

Water represents more than $90 \%$ of the fresh weight of most plant tissues in the growth phase and it is essential for maintaining turgidity and cell expansion (Steinbrecher and Leubner-Metzger, 2017). In germination, the hydration process results from the difference in water potentials between cells and the medium, and this varies from one type of seed to another. This imbibition is fundamental for activating seed metabolism, directly affecting the physiological processes that precede root protrusion, such as respiration, mitochondrial multiplication and repair, mobilization of reserves, and DNA synthesis and repair (Nonogaki, et al., 2010).

Water movement in the tissues occurs through three routes: the apoplastic, symplastic, and transcellular pathways (Kshetrimayum, et al., 2017). In the apoplastic pathway, water passes through the intercellular spaces through pores in the cell wall. In the symplastic pathway, water movement occurs through plasmodesmata that interconnect the membranes of neighboring cells, creating cytoplasmic bridges. The transcellular pathway involves the movement of water through the cell membranes, in water selective channels known as aquaporins (Preston, et al., 1992; Martínez-Ballesta, et al., 2016; Qi, et al., 2016).

The involvement of aquaporins in seed hydration during germination has been shown through analysis of gene expression in different plant species, such as Brassica napus (Ge, et al., 2014), Medicago truncatula (Bouton, et al., 2005), Arabidopsis thaliana (Gattolin, et al., 2011), Oryza sativa (Liu, et al., 2013), Spinacia oleracea (Chen, et al., 2013), and Vicia faba (Novikova, et al., 2014).

One of the possibilities for estimating the contribution of aquaporins in water transport in plant tissues is through use of agents that block these water channels, such as mercuric chloride $\left(\mathrm{HgCl}_{2}\right)$ (Daniels, et al., 1996; Javot and Maurel, 2002). The mercury $(\mathrm{Hg})$ interacts with thiol groups of the cysteine residues, oxidizing them and blocking the activity of the aquaporins (Agre, et al., 1998; Aroca, et al., 2012). This blockage can be reversed using dithiothreitol (DTT) or 2-mercaptoethanol, which induce reduction in the sulfhydryl groups, allowing aquaporins to return to their original form and function (Jain, et al., 2008; Obroucheva, et al., 2012).
In addition to the damage that heavy metals like $\mathrm{Hg}$ cause to aquaporins, they are directly or indirectly associated with various types of cell damage, such as oxidative stress (Koivula and Eeva, 2010), which leads to oxidation of proteins and damage to the plasmatic membrane and to DNA (Gajewska and Slodowska, 2008; Ahmad, et al., 2010; Gill and Tuteja, 2010).

Heavy metal pollution from artisanal or smallscale mining operations is recognized as a significant environmental problem, with $\mathrm{Hg}$ being prominent in gold extraction process, especially in tropical developing countries (Adjei-Kyereme, et al., 2015). In Brazil, $\mathrm{Hg}$ pollution has been recorded in different areas. The contamination in the Southeast region decreased, but it increased in the North region in the last quarter of the 20th century (Hacon, et al., 2008).

Popularly known as guapuruvu or ficheira, Schizolobium parahyba (Vell.) Blake grows from Bahia to Rio Grande do Sul State, Brazil (Ferreira, et al., 2007). This species has a potential for restoration of riparian forests and for many other purposes, in which its wood and bark can be used (Coneglian, et al., 2016). With the characteristics of a pioneer species and rapid growth (Sereda, et al., 2008; Freire, et al., 2015) in native environment, this species can reach a volumetric production of 45 $\mathrm{m}^{3}$. ha-1. year-1, over 10 years (Narita, et al., 2018). It can be used in the making of diverse objects, such as toys (Lorenzi, 2002), furniture, packaging, and wooden boxes (Bortoletto Júnior and Belini, 2002), as well as for production of cellulose and paper (Nisgoski, et al., 2012).

Considering the importance of the species in the production of diverse products, lack of information on germination in soils contaminated by mercury, and the processes involved in seed hydration by aquaporins, the aim of this study was to evaluate the effects of $\mathrm{HgCl}_{2}$ and DTT on aquaporins activity and on the integrity/degradation of DNA in embryonic axes of $S$. parahyba during the germination process.

\section{MATERIALS AND METHODS}

S. parahyba fruits were collected from 20 trees in the municipality of Viçosa, Minas Gerais, Brazil (20'45'14"S, 42 52'55"W) in September, 2015. A homogenous group of seeds was obtained from this

Revista Árvore 2019;43(6):e430601 
collection for subsequent analyses. Moisture content (MC) was determined by oven method at $103{ }^{\circ} \mathrm{C}$ for $17 \mathrm{~h}$ (ISTA, 2004) using five replications of 20 seeds. The viability of fresh seeds was evaluated by germination test (Ferreira, et al., 2007). After mechanical scarification using a sand paper, the seeds were placed in Petri dishes $(\varnothing=150 \mathrm{~mm})$ over two moistened germination papers and incubated at $25{ }^{\circ} \mathrm{C}$ under constant light. Five replications of 20 seeds each were used, and the germination was scored daily.

The embryonic axes used in evaluation of aquaporins activity were obtained by cutting the seed coats laterally and crosswise using a micro circular saw blade coupled to a multipurpose rotary tool, and extraction of the embryonic axes with a tweezers.

The embryo weight and length were evaluated by using five replications of 10 embryos each, arranged in Petri dishes $(\varnothing=90 \mathrm{~mm})$ between germitest papers, moistened with $2.5 \mathrm{~mL}$ of $\mathrm{H}_{2} \mathrm{O}$ (control) or with the same amount of $\mathrm{HgCl}_{2}$ or DTT. In all phases of the experiment, the Petri dishes were sealed with parafilm tape and incubated in the dark in biochemical oxygen demand (BOD) at $25^{\circ} \mathrm{C}$ and constant lighting provided by four $20 \mathrm{~W}$ bulbs with daylight type lighting. Elongation of the embryonic axes was measured through scaled images, registered by a digital camera coupled to a stereomicroscope (Zeiss) and processed with the aid of the software AxioVision Rel. 4.8. The gain in fresh weight of the embryonic axes was quantified on a digital analytical balance.

The concentration of $\mathrm{HgCl}_{2}$ necessary to inhibit aquaporins activity was determined through variation in fresh weight, which was verified by the difference between the weight of the embryonic axes exposed to the concentrations of $0.01,0.1,1.0$, and $5 \mathrm{mM}$ and in water (control) for 72 hours. After this step, the concentration of $5 \mathrm{mM} \mathrm{HgCl}_{2}$ was selected for the subsequent trials.

In restoration of aquaporins activity, the embryonic axes were soaked in $5 \mathrm{mM} \mathrm{HgCl}_{2}$ for 48 hours and were then transferred to $5 \mathrm{mM}$ DTT solution or $\mathrm{H}_{2} \mathrm{O}$. After 24 hours, resumption of weight gain was evaluated. The trials for evaluation of imbibition and restoration of aquaporins activity were performed with five replications of 10 embryonic axes.
To evaluate the integrity of the DNA, controls were used to simulate intact DNA (fresh leaves of Copaifera langsdorffii) and degraded DNA (embryonic axes of $S$. parahyba placed in boiling $\mathrm{H}_{2} \mathrm{O}$ for two minutes). DNA extraction followed the protocol adapted from Masetto, et al. (2008) using hexadecyltrimethylammonium bromide (CTAB). The samples were ground in liquid nitrogen, transferred to $2 \mathrm{~mL}$ microtubes, to which were added $700 \mu \mathrm{L}$ of the CTAB $2 \mathrm{x}$ buffer, and preheated to $65^{\circ} \mathrm{C}$, keeping the microtubes incubated at this same temperature for an hour, with homogenization every 10 minutes. After that, $600 \mu \mathrm{L}$ of chloroform-isoamyl alcohol (24:1) was added to the microtubes, inverting them periodically in a 5-minute period. After this step, they were centrifuged at $12,000 \mathrm{rpm}$ for 10 minutes at room temperature. Six hundred microliter of the supernatant was transferred to another microtube and $450 \mu \mathrm{L}$ of cold isopropanol was added, keeping the tubes at $-20{ }^{\circ} \mathrm{C}$ for 12 hours. The tubes were then centrifuged at $12,000 \mathrm{rpm}$ at $4{ }^{\circ} \mathrm{C}$ for $10 \mathrm{~min}$, and the supernatant was discarded. The residue was washed twice with $1 \mathrm{~mL}$ of $70 \%$ ethanol for $5 \mathrm{~min}$ and with 1 $\mathrm{mL}$ of $95 \%$ ethanol for $3 \mathrm{~min}$. The residue was dried in a paper filter and dissolved in $50 \mu \mathrm{L}$ of $\mathrm{TE}, \mathrm{pH}$ 8.0 (10 mM Tris- $\mathrm{HCl}$ and $1 \mathrm{mM}$ EDTA). The DNA samples were loaded on a $1 \%$ agarose gel with $0.01 \%$ GelRed $^{\mathrm{TM}}$ and subjected to electrophoresis. The integrity of chromosomal DNA was evaluated using three replications of 10 embryonic axes.

A completely randomized design (CRD) was used in all experimental steps. Experimental evaluations were performed in 24-hour intervals for 72 hours. The results were subjected to ANOVA, followed by regression analysis. Similarity among the models $(\mathrm{p} \leq 0.05)$ was tested through the Model Identity Test (Regazzi, 1993). All statistical analyses were performed on software R for Windows ${ }^{\circledR}$ 2.12.0 (R Development Core Team, 2011). The figures were edited on SigmaPlot 11.0 software.

\section{RESULTS}

The moisture content (MC) of the seeds was $9.2 \%$ (fresh weight basis). Hydration of the excised embryonic axes kept in water (control) for $72 \mathrm{~h}$ resulted in fresh weight 5.51 times greater than weight observed before imbibition (Figure 1). Upon exposing the axes to $0.01,0.1$ and $1 \mathrm{mM} \mathrm{HgCl}{ }_{2}$, gains in fresh 


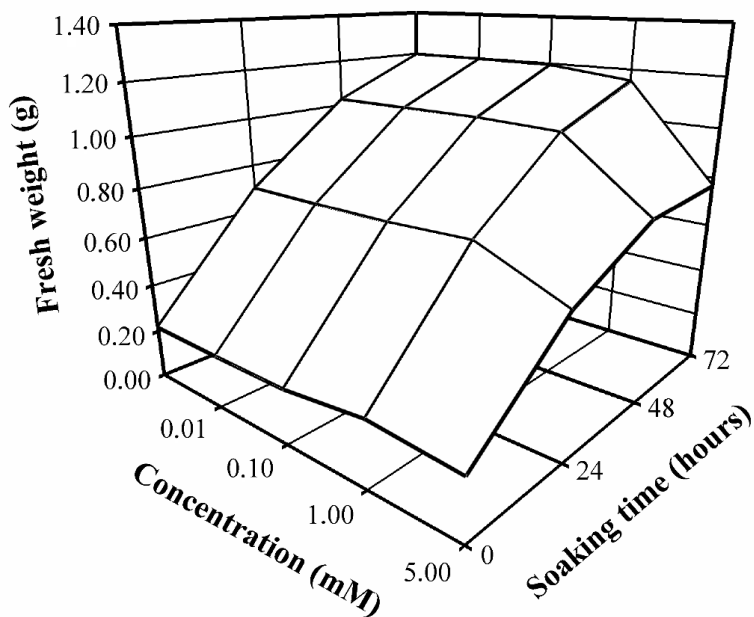

Figure 1 - Fresh weight (g) of the embryonic axes of $S$. parahyba over the period of 72 hours of soaking in $\mathrm{H}_{2} \mathrm{O}$ (control) and $\mathrm{HgCl}_{2}$ solutions at $0.01,0.1,1$, and $5 \mathrm{mM}^{2}$.

Figura 1 - Peso fresco $(g)$ dos eixos embrionários de $\boldsymbol{S}$. parahyba durante o período de 72 horas de embebição em $\mathrm{H}_{2} \mathrm{O}$ (controle) e soluções de $\mathrm{HgCl}_{2}$ a 0,01, 0,1, 1 e $5 \mathrm{mM}$.

weight were found analogous to the control treatment (Figure 1). Delays in weight gain in the embryonic axes were exhibited after 6 hours of soaking in $5 \mathrm{mM}$ $\mathrm{HgCl}_{2}$, extending up to 72 hours (Figure 1 and 2).

The observed gain in fresh weight was the same as observed for the control treatment upon soaking the embryonic axes in $5 \mathrm{mM}$ DTT, showing that there was no effect of DTT on hydration of the axes during the soaking process (Figure 2A). In addition, when testing lower DTT concentrations (0.01, 0.1 and $1 \mathrm{mM}$ ) this same tendency was observed (data not shown).

Restoration of the aquaporins activity in the embryonic axes soaked for 48 hours in $\mathrm{HgCl}_{2}$ (5 $\mathrm{mM}$ ) followed by exposure for 24 hours to DTT (5 $\mathrm{mM}$ ) is shown by resumption of imbibition (Figure 2B). Thus, embryonic axes transferred to DTT and $\mathrm{H}_{2} \mathrm{O}$ showed gain in fresh weight of $47 \%$ and $14 \%$, respectively, greater than that obtained in the embryonic axes that remained soaking in $\mathrm{HgCl}_{2}$. Significant change was also found in the pattern of expansion of the embryonic axes exposed to $\mathrm{HgCl}_{2}$ (Figure 3).

These changes resulted in reduction in the elongation of the embryonic axis in all the periods evaluated, especially after $72 \mathrm{~h}$ of soaking in the $\mathrm{HgCl}_{2}$ solution (Figure 4A). Upon transferring

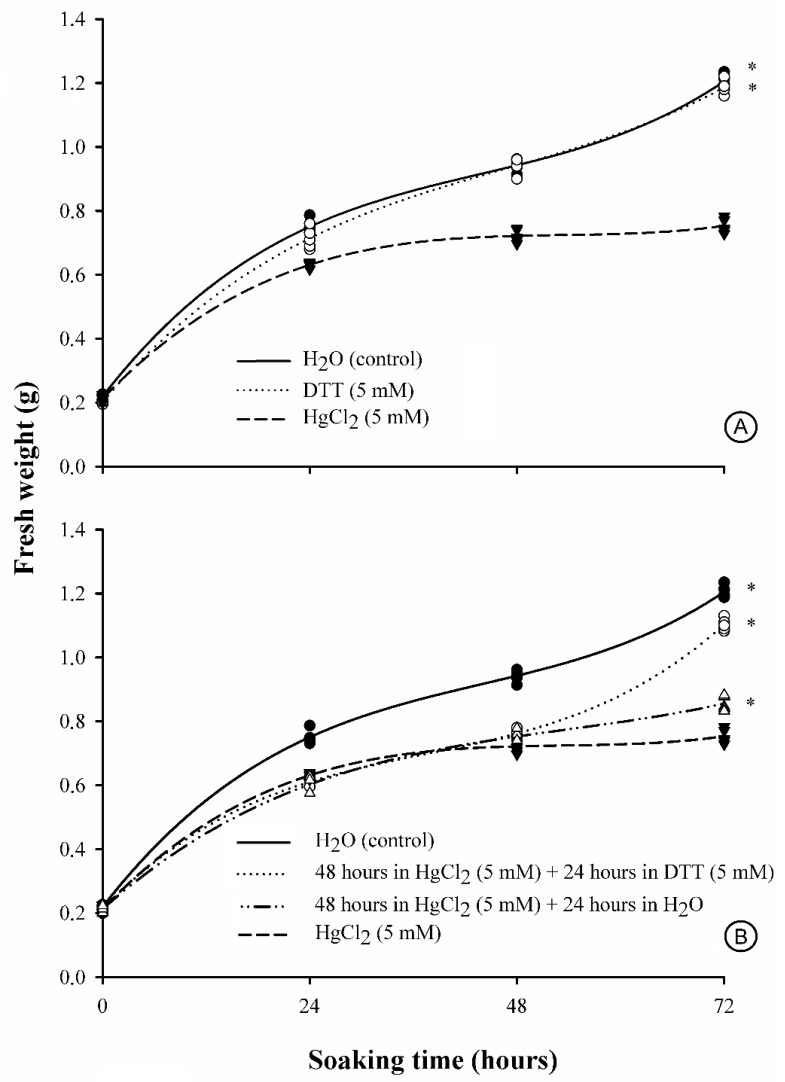

Figure 2 - Hydration curves of the embryonic axes of S. parahyba over the period of 72 hours of soaking. (A) Inhibition of aquaporins activity and (B) reversal of inhibition of aquaporins activity. * represents difference of equations in relation to the axes soaked in $\mathrm{HgCl}_{2}$, at a significance level of $5 \%$ probability.

Figura 2 - Curvas de hidratação dos eixos embrionários de $\boldsymbol{S}$. parahyba durante o período de 72 horas de embebição. Inibição da atividade das aquaporinas (A) e reversão da inibição da atividade das aquaporinas (B). * representa a diferença de equações em relação aos eixos embebidos em $\mathrm{HgCl}_{2}$, a um nível de significância de 5\% de probabilidade.

the embryonic axes kept in $\mathrm{HgCl}_{2}$ solution to the DTT and $\mathrm{H}_{2} \mathrm{O}$ solution, significant resumption in elongation of the embryonic axis was observed (Figure 4B) after 24 hours of exposure, achieving values $44 \%$ and $9 \%$ greater, respectively, than those that remained soaking in $\mathrm{HgCl}_{2}$.

Upon evaluating the integrity of the DNA in the embryonic axes soaked in water, $5 \mathrm{mM} \mathrm{HgCl}_{2}$, or in DTT, degradation was not observed over the period of 72 hours of soaking (Figure 5), maintaining the same pattern in the treatments in which the reversal of inhibition was evaluated (Figure 5)

\section{Revista Árvore 2019;43(6):e430601}




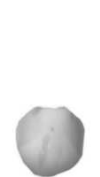

0 hours

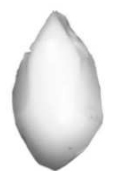

24 hours

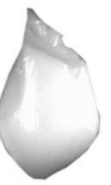

24 hours

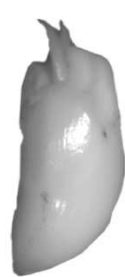

48 hours

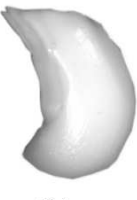

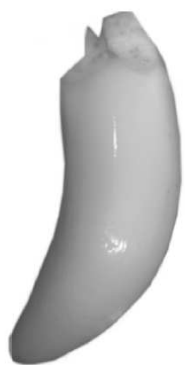

72 hours

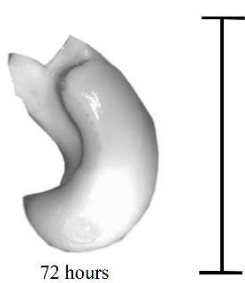

(A)

(B)
Figure 3 - Growth of the embryonic axes of $S$. parahyba over the period of 72 hours of soaking in water (A) and $5 \mathrm{mM}$ $\mathrm{HgCl}_{2}$ (B). Scale bar: $1 \mathrm{~cm}$.

Figura 3 - Crescimento dos eixos embrionários de $\boldsymbol{S}$. parahyba durante o período de 72 horas de embebição em água (A) e $5 \mathrm{mM}$ de $\mathrm{HgCl}_{2}$ (B). Barra de escala: $1 \mathrm{~cm}$.

\section{DISCUSSION}

The moisture content (MC) of $S$. parahyba seeds is normally under $10 \%$, according to data of Ferreira, et al. (2007), who found values of $8.2 \%$ and $7.8 \%$, and by Cherobini, et al. (2010), who obtained values of $8.2,6.3$, and $7.1 \%$ in an evaluation of three seed lots. Studies have shown that $S$. parahyba seeds have high viability after dispersion, achieving germination percentages higher than $85 \%$ when dormancy is broken (Ferreira, et al., 2007; Magalhães, et al., 2010). In this study, the seeds had 95\% germination after mechanical scarification, beginning root protrusion on the seventh day.

Concentrations of $\mathrm{HgCl}_{2}$ up to $1 \mathrm{mM}$ proved to have no effect on the imbibition process of the embryonic axes, indicating that significant damage to the aquaporins that would result in blocking the passage of water did not occur (Figure 1). It is possible that at lower concentrations the $\mathrm{Hg}$ is not enough to inhibit all the aquaporins in the plasmatic membranes and the tonoplast. In addition, part of the $\mathrm{Hg}$ could be distributed and adsorbed in the outermost cell layers, not affecting the activity of enzymes that act in expansion of the axis or even not inhibiting aerobic

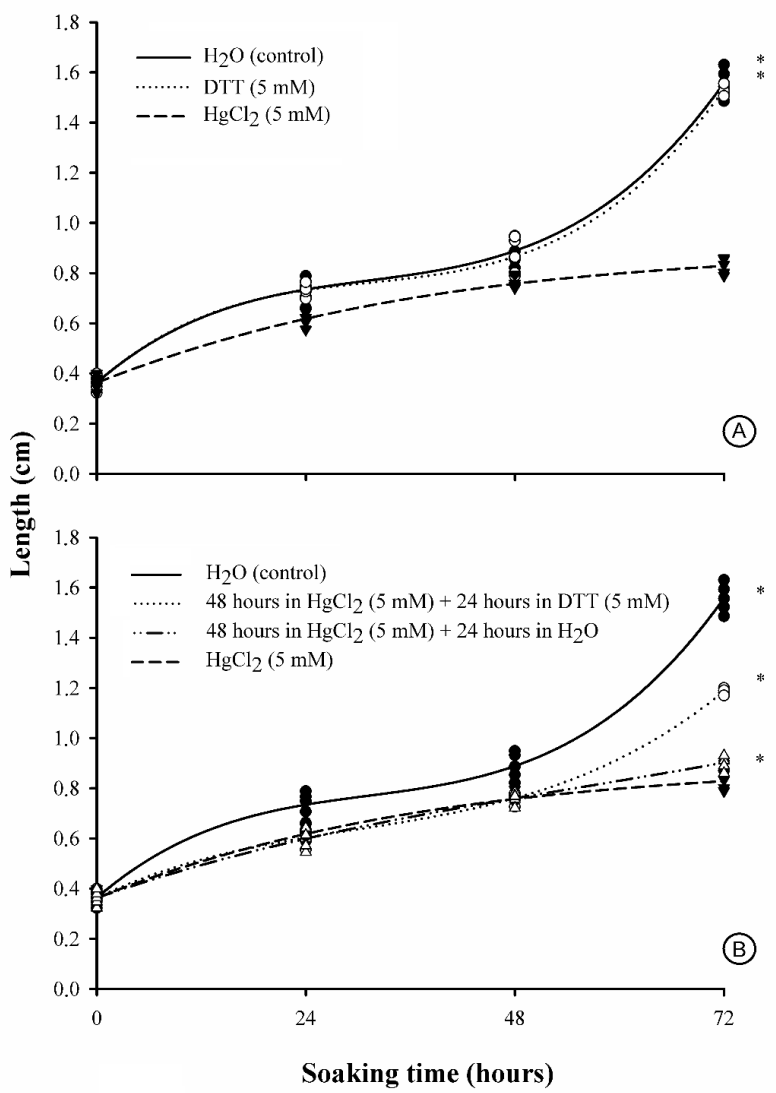

Figure 4 - Elongation of the embryonic axes of $S$. parahyba over the period of 72 hours of soaking. (A) Inhibition of aquaporins activity and (B) reversal of inhibition of aquaporins activity. $*$ represents difference of equations in relation to the axes soaked in $\mathrm{HgCl}_{2}$, at a significance level of $5 \%$ probability.

Figura 4 - Elongamento dos eixos embrionários de $\boldsymbol{S}$. parahyba durante o período de 72 horas de embebição. Inibição da atividade das aquaporinas $(A)$ e reversão da inibição da atividade das aquaporinas $(B)$. * representa a diferença de equações em relação aos eixos embebidos em $\mathrm{HgCl}$, a um nível de significância de $5 \%$ de probabilidade.

metabolism. Thus, imbibition related to aquaporins activity would not be impeded in a detectable manner.

At higher concentration (5 mM), however, inhibition of aquaporins activity was observed, with reduction in fresh weight gain (Figures 1 and 2) and in elongation of the embryonic axis of $S$ parahyba (Figures 3 and 4) were observed after 6 hours of soaking. Such results indicate that water transport through the aquaporins during phase I of imbibition was seriously affected by the presence of $\mathrm{Hg}$. Similar results were found in Plathymenia reticulata seeds 


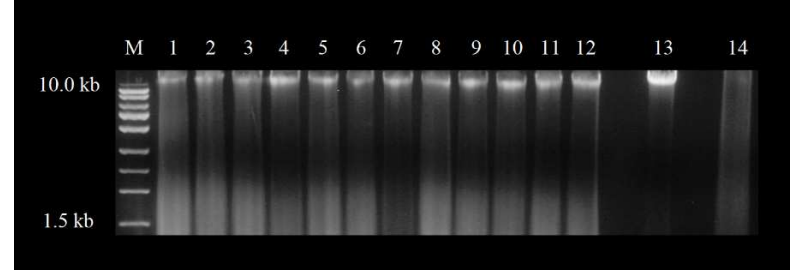

Figure 5 - Integrity of the chromosomal DNA in the embryonic axes of $S$. parahyba during inhibition and reversal of inhibition of aquaporins activity. M - marker, 1 - embryonic axes not soaked, 2 - 24 hours in $\mathrm{H}_{2} \mathrm{O}$ (control), 3 - 48 hours in $\mathrm{H}_{2} \mathrm{O}$ (control), 4 - 72 hours in $\mathrm{H}_{2} \mathrm{O}$ (control), 5 - 24 hours in $\mathrm{HgCl}_{2}(5 \mathrm{mM}), 6-48$ hours in $\mathrm{HgCl}(5 \mathrm{mM}), 7$ - 72 hours in $\mathrm{HgCl}_{2}(5 \mathrm{mM}), 8$ 24 hours in DTT $(5 \mathrm{mM}), 9-48$ hours in DTT $(5 \mathrm{mM})$, 10 - 72 hours in DTT $(5 \mathrm{mM}), 11-48$ hours in $\mathrm{HgCl}_{2}$ $(5 \mathrm{mM})+24$ hours in DTT $(5 \mathrm{mM}) ; 12-48$ hours in $\mathrm{HgCl}_{2}(5 \mathrm{mM})+24$ hours in $\mathrm{H}_{2} \mathrm{O}, 13$ - positive control (Copaifera langsdorffii leaves), 14 - positive control (dead embryonic axes of $S$. parahyba, after two minutes in water at $98^{\circ} \mathrm{C}$ ).

Figura 5 - Integridade do DNA cromossômico nos eixos embrionários de $\boldsymbol{S}$. parahyba durante a inibição $e$ reversão da inibição da atividade das aquaporinas. $M$ marcador, 1 - eixos embrionários não embebidos, 2 - 24 horas em $\mathrm{H}_{2} \mathrm{O}$ (controle), 3 - 48 horas em $\mathrm{H}_{2} \mathrm{O}$ (controle), 4 - 72 horas em $\mathrm{H}_{2} \mathrm{O}$ (controle), 5 - 24 horas em $\mathrm{HgCl}_{2}$ (5 mM), 6 - 48 horas em $\mathrm{HgCl}_{2}(5 \mathrm{mM}), 7$ - 72 horas em $\mathrm{HgCl}_{2}(5 \mathrm{mM}), 8$ - 24 horas em DTT (5 mM), 9 - 48 horas em DTT (5 mM), 10 - 72 horas em DTT $(5 \mathrm{mM})$, 11 - 48 horas em $\mathrm{HgCl},(5 \mathrm{mM})+24$ horas em DTT $(5$ $m M), 12$ - 48 horas em $\mathrm{HgCl},(5 \mathrm{mM})+24$ horas em $\mathrm{HO}$, 13 - controle positivo (folhas de Copaifera langsdorffii), 14 - controle positivo (eixos embrionários mortos de $S$. parahyba, após dois minutos em água a $98^{\circ} \mathrm{C}$ ).

(Cardoso, et al., 2015) and embryonic axes of Aesculus hippocastanum (Obroucheva, et al., 2012) and Vicia faba (Novikova, et al., 2014), where hydration kinetics were inhibited by $\mathrm{HgCl}_{2}$ in the initial hours of imbibition.

Studies show that seeds of different plant species vary widely in terms of response to soaking time and to concentrations of $\mathrm{HgCl}_{2}$ in the medium, which is related to whether aquaporins activity is inhibited or not. In Solanum esculentum seeds, imbibition was affected after 12 hours of exposure to 10, 20, and 30 $\mu \mathrm{M} \mathrm{HgCl}_{2}$ (Jain, et al., 2008), whereas in embryonic axes of Aesculus hippocastanum (Obroucheva, et al., 2012) and Vicia faba (Novikova, et al., 2014), hydration decreased after 15 hours of soaking at 0.75 and $0.5 \mathrm{mM} \mathrm{HgCl}_{2}$, respectively.

The toxic action of $\mathrm{Hg}$ on the protein structures occurs predominantly by oxidation of the thiol groups, resulting in modification of the three-dimensional shape of the aquaporins and, consequently, in reduction in water transport (Daniels, et al., 1996; Tyerman, et al., 1999; Savage and Stroud, 2007; Aroca, et al., 2012). The operability of these structures, however, can be reestablished through reducing agents, such as DTT, which acts to protect and reduce the sulfhydryl groups, allowing resumption of water transport (Maurel, et al., 1993; Javot, et al., 2002; Jain, et al., 2008). Thus, the results obtained in S. Parahyba indicate that DTT was able to reestablish aquaporins activity in the embryonic axes during the germination process. Such results indicate that resumption of water uptake as a result of restoration of aquaporins activity was sufficient to modify cell turgor pressure and promote expansion of embryonic axes.

The use of DTT to unblock aquaporins inhibited by $\mathrm{HgCl}_{2}$ during the germination process has already been shown in Aesculus hippocastanum and Vicia faba from results obtained after 15 hours of exposure to DTT (Obroucheva, et al., 2012; Novikova, et al., 2014). When DTT was used simultaneously with $\mathrm{HgCl}_{2}$ (both $1 \mathrm{mM}$ ) in Plathymenia reticulata seeds, it was found that there was no inhibition of aquaporins activity during the germination process (Cardoso, et al., 2015).

Cell expansion is assisted by the combination of increase in cell turgor pressure, due to resumption of water uptake, and by reduction in the retaining forces in cell walls (Nonogaki, et al., 2010; Steinbrecher and Leubner-Metzger, 2017). Since they are involved in water transport during the germination process, aquaporins also play a crucial role in cell expansion. This participation was clear in the results obtained in embryonic axes of $S$. parahyba, soaked in $5 \mathrm{mM}$ $\mathrm{HgCl}_{2}$ up to 72 hours, with significant reduction in elongation (Figure 4A). Results that show the role of aquaporins in the seed germination process were also observed in Arabidopsis thaliana seeds, in which elongation of the embryonic axis during the germination process was less in seeds soaked in $5 \mu \mathrm{M}$ $\mathrm{HgCl}_{2}$ compared to seeds soaked in water (Willigen, et al., 2006).

Aesculus hippocastanum seeds (Obroucheva, et al., 2012) soaked in $0.5 \mathrm{mM} \mathrm{HgCl}$, solution did not undergo a reduction in elongation of the embryonic axis. However, the solution brought about reversible delays in the initial growth of the embryonic axes after root protrusion. Likewise, in seeds of Vigna radiata

Revista Árvore 2019;43(6):e430601 
(Jagatheeswari and Ranganathan, 2012), Platanus occidentalis, Pinus echinata and Pinus taeda (JeanPhilippe, et al., 2012), Linum usitatissimum (Jain, 2013), and Plathymenia reticulata (Cardoso, et al., 2015), root protrusion was also negatively affected upon exposing seeds to mercury compounds during the germination process.

During the germination process, the activation of cellular metabolism induces a series of events, such as DNA repair and synthesis, both crucial for seed germination and initial seedling growth (Nonogaki, et al., 2010). Under stress conditions, such as the presence of heavy metals, cell metabolism induces high production of reactive oxygen species that can promote DNA cleavage, modifying from 10,000 to 100,000 base pairs in a single cell per day (Kranner and Colville, 2011; Štolfa, et al., 2015). The embryonic axes of $S$. parahyba exposed to $\mathrm{Hg}$, however, did not exhibit damage to DNA, which may be a result of the effective action of the cell antioxidant system, promoting elimination or reduction in the concentrations of reactive oxygen species.

\section{CONCLUSION}

We conclude that the exposure time and the concentration of $\mathrm{HgCl}_{2}$ were not sufficient to induce damage to DNA, but were able to reduce gains in fresh weight and elongation of the embryonic axis during germination, possibly by toxic action on aquaporins activity. This effect was partially reversed using agents that protect the thiol groups, such as DTT.

\section{ACKNOWLEDGEMENTS}

We thank CAPES for financial support through the Projeto Pró-Amazônia, n. 52 and to the CNPQ for the research productivity scholarship to the second author. We also thank CAPES for scientific scholarship to the first author.

\section{REFERENCES}

Adjei-Kyereme Y, Donkor AK, Golow AA, Yeboah PO, Pwamang J. Mercury Concentrations in Water and Sediments in Rivers Impacted by Artisanal Gold Mining in the Asutifi District, Ghana. Research Journal of Chemical and Environmental Sciences. 2015;3(1):40-48.
Agre P, Bonhivers M, Borgnia MJ. The aquaporins, blueprints for cellular plumbing systems. Journal of Biological Chemistry. 1998;273(24):14659-14662. doi: $10.1074 /$ jbc.273.24.14659

Ahmad P, Jaleel CA, Salem MA, Nabi G, Sharma S. Roles of enzymatic and nonenzymatic antioxidants in plants during abiotic stress. Journal Critical Reviews in Biotechnology. 2010;30(3):161-175. doi: $10.3109 / 07388550903524243$.

Aroca R, Porcel R, Ruiz-Lozano JM. Regulation of root water uptake under abiotic stress conditions. Journal of Experimental Botany. 2012;63(1):43-57. doi: $10.1093 / \mathrm{j} x b /$ err266.

Bortoletto Júnior G, Belini UL. Produção de lâminas e manufatura de compensados a partir da madeira de guapuruvu (Schizolobium parayba Blake) proveniente de um plantio misto de espécies nativas. Cerne. 2002;8(2):16-28. [accessed: 11 February 2018]. Available from: http://cerneuflabr/ site/indexphp/CERNE/article/download/599/509/

Bouton S, Viau L, Lelièvre E, Limami AM. A gene encoding a protein with a proline-rich domain (MtPPRD1), revealed by suppressive subtractive hybridization ( $\mathrm{SSH})$, is specifically expressed in the Medicago truncatula embryo axis during germination. Journal of Experimental Botany. 2005;56(413):825-832. doi: 10.1093/jxb/eri077.

Cardoso AA, Borges EEL, Souza GA, Silva CJ, Pires RMO, Dias DCFS. Seed imbibition and germination of Plathymenia reticulata Benth (Fabaceae) affected by mercury: possible role of aquaporins. Acta Botanica Brasilica. 2015;29:285291. doi:101590/0102-33062014abb0038

Chen K, Fessehaie B, Arora R. Aquaporin expression during seed osmopriming and postpriming germination in spinach. Biologia Plantarum. 2013;57(1):193-198. doi: /doi.org/10.1007/s10535012-0266-0.

Cherobini EAI, Lazarotto M, Muniz MFB, Girardi LB, Lippert DB, Maciel CG. Qualidade de sementes e mudas de Schizolobium parahyba procedentes do Rio Grande do Sul, Santa Catarina e Paraná. Cerne. 2010;16(3):407-413. doi: dx.doi.org/10.1590/S010477602010000300017 .

Coneglian A, Ribeiro PHP, Melo BS, Pereira RF, 
Dorneles Junior J. Initial growth of Schizolobium parahybae in Brazilian Cerrado soil under liming and mineral fertilization. Revista Brasileira de Engenharia Agrícola e Ambiental. 2016;20(10):908912. doi: dx.doi.org/10.1590/1807-1929/agriambi. v20n10p908-912.

Daniels MJ, Chaumont F, Mirkov TE, Chrispeels MJ. Characterization of a new vacuolar membrane aquaporin sensitive to mercury at a unique site. The Plant Cell. 1996;8(4):587-599. doi: 10.1105/ tpc.8.4.587.

Ferreira RA, Oliveira LM, Tonetti OAO, Davide AC. Comparação da viabilidade de sementes de Schizolobium parahyba (vell) Blake - leguminosae Caesalpinioideae, pelos testes de germinação e tetrazólio. Revista brasileira de sementes. 2007;29(3):83-89. doi: dx.doi.org/10.1590/S010131222007000300011 .

Freire JM, Piña-Rodrigues FCM, Santos ALF, Pereira MB. Intra- and inter-population variation in seed size and dormancy in Schizolobium parahyba (Vell) Blake in the Atlantic Forest. Ciência Florestal. 2015;25(4):897-907. doi: dx.doi. org/10.5902/1980509820592.

Gajewska E, Sklodowska M. Differential biochemical responses of wheat shoots and roots to nickel stress: antioxidative reactions and proline accumulation. Plant Growth Regulation. 2008;54(2):179-188. doi: doi.org/10.1007/s10725-007-9240-9.

Gattolin S, Sorieul M, Frigerio L. Mapping of tonoplast intrinsic proteins in maturing and germinating Arabidopsis seeds reveals dual localization of embryonic TIPs to the tonoplast and plasma membrane. Molecular Plant. 2011;4(1):180189. doi: $10.1093 / \mathrm{mp} / \mathrm{ssq} 051$.

Ge FW, Tao P, Zhang Y, Wang JB. Characterization of AQP gene expressions in Brassica napus during seed germination and in response to abiotic stresses. Biologia Plantarum. 2014;58(2):274-282. doi: 10.1007/s10535-013-0386-1.

Gill SS, Tuteja N. Reactive oxygen species and antioxidant machinery in abiotic stress tolerance in crop plants. Plant Physiology and Biochemistry. 2010;48(12):909-930. doi: 101016/jplaphy201008016.

Hacon S, Barrocas PRG, Vasconcellos ACS,
Barcellos C, Wasserman JC, Campos RC, Ribeiro C, Azevedo-Carloni FB. An overview of mercury contamination research in the Amazon basin with an emphasis on Brazil. Cadernos de Saúde Pública. 2008;24(7):1479-1492. doi: dx.doi.org/10.1590/ S0102-311X2008000700003.

International Seed Testing Association (ISTA). International rules for seed testing. Bassersdorf: Switzerland; 2004. [accessed: 21 February 2018]. Available from: https://www.seedtest.org/upload/ cms/user/09Int-M-D200509ActivityReport2004.pdf

Jagatheeswari D, Ranganathan P. Influence of mercuric chloride on seed germination, seedling growth and biochemical analysis of green gram (Vigna radiata (L) Wilczek Var Vamban-3). International Journal of Pharmaceutical \& Biological Archives. 2012;3(2):291-295. [accessed: 12 February 2018]. Available from: https://wwwgooglecombr/ url? $\mathrm{sa}=\mathrm{t} \& \mathrm{rct}=\mathrm{j} \& \mathrm{q}=\&$ esrc $=\mathrm{s} \&$ source $=$ web $\& \mathrm{~cd}$ 1\&ved=0ahUKEwjGiLbL5PrWAhVHI5AKHT 31A50QF ggqMAA\&url=http $\% 3 \mathrm{~A} \% 2 \mathrm{~F} \% 2 \mathrm{~F}$ wwwijpbainfo\%2Fijpba\%2Findexphp $\% 2$ Fijpba $\% 2$ Farticle\%2FviewFile\%2F593\%2F403\&usg=AOv Vaw 2WLKcPuCxv NpdvovwssIJs

Jain N, Ascough GD, Staden JV. A smoke-derived butenolide alleviates $\mathrm{HgCl}_{2}$ and $\mathrm{ZnCl}_{2}$ inhibition of water uptake during germination and subsequent growth of tomato - possible involvement of aquaporins. Journal of Plant Physiology. 2008;165(13):1422-1427. doi: 10.1016/j. jplph.2008.04.017.

Jain RK. Study of heavy metals effect in response to linum seed germination. African Journal of Plant Science. 2013;7(3):93-109. doi: doi.org/10.5897/ AJPS11.169.

Javot H, Maurel C. The role of aquaporins in root water uptake. Annals of Botany. 2002;90(3):301313. doi: 10.1093/aob/mcf199.

Jean-Philippe SR, Labbé N, Damay J, Franklin JA, Hughes K. Effect of mercuric compounds on Pine and Sycamore germination and early survival. American Journal of Plant Sciences. 2012;3(1):150158. doi: 10.4236/ajps.2012.31017.

Koivula MJ, Eeva T. Metal-related oxidative stress in birds. Environmental Pollution. 2010;158(7):2359-2370. doi: 10.1016/j. envpol.2010.03.013.

\section{Revista Árvore 2019;43(6):e430601}


Kranner I, Colville L. Metals and seeds: biochemical and molecular implications and their significance for seed germination. Environmental and Experimental Botany. 2011;72(1):93-105. doi: 10.1016/j. envexpbot.2010.05.005.

Kshetrimayum E, Sahoo DP, Mitra J, Panda SK. Regulation of Seed Germination and the Role of Aquaporins under Abiotic Stress. International Journal of Environment, Agriculture and Biotechnology. 2017;2(2):607-615. doi: 10.22161/ ijeab/2.2.7.

Liu C, Fukumoto T, Matsumoto T, Gena P, Frascaria D, Kaneko T, Katsuhara M, Zhong S, Sun X, Zhu Y, Iwasaki I, Ding X, Calamita G, Kitagawa Y. Aquaporin OsPIP1;1 promotes rice salt resistance and seed germination. Plant Physiology and Biochemistry. 2013;63:151-158. doi: 10.1016/j. plaphy.2012.11.018.

Lorenzi H. Árvores brasileiras: Manual de identificação e cultivo de plantas arbóreas nativas do Brasil. $2^{\mathrm{a}}$ ed. Nova Odessa: Instituto Plantarum; 2002. v. 3

Magalhães SR, Borges EEL, Berger APA. Mobilização de reservas no eixo embrionário e nos cotilédones de sementes de Schizolobium parahyba (vell) S. F. Blake durante a germinação. Ciência Florestal. 2010;20(4):589-595. [accessed: 18 February 2018]. Available from: https:// periodicosufsmbr/cienciaflorestal/article/ view/2417/1495

Martínez-Ballesta MDC, Pérez-Sánchez H, Moreno DA, Carvajal M. Plant plasma membrane aquaporins in natural vesicles as potential stabilizers and carriers of glucosinolates. Colloids and Surfaces. B, Biointerfaces. 2016;143:318-326. doi: 10.1016/j. colsurfb.2016.03.056.

Masetto TE, Faria JMR, Davide AC, Silva EAA. Desiccation tolerance and DNA integrity in Eugenia pleurantha O Berg (Myrtaceae) seeds. Revista Brasileira de Sementes. 2008;30(1):175-180. doi: dx.doi.org/10.1590/S0101-31222008000100022.

Maurel C, Reizer J, Schroeder JI, Chrispeels MJ. The vacuolar membrane protein $\gamma$-TIP creates water specific channels in Xenopus oocytes. The EMBO Journal. 1993;12(6):2241-2247. [accessed 12 February 2018]. Available from: https://
wwwncbinlmnihgov/pmc/articles/PMC413452/pdf/ emboj00078-0022pdf

Narita DK, Nakashima GT, Róz AL, Pires AAF, Yamaji FM. Uso do guapuruvu (Schizolobium parahyba) para fins energéticos. Ciência Florestal. 2018;28(2):758-764. doi: dx.doi. org/10.5902/1980509832089.

Nisgoski S, Muñiz GIB, Trianoski R, Matos JLM, Venson I. Características anatômicas da madeira e índices de resistência do papel de Schizolobium parahyba (Vell) Blake proveniente de plantio experimental. Scientia Forestalis. 2012;40(94):203211. [accessed: 13 February 2018]. Available from: http://wwwipefbr/publicacoes/scientia/nr94/ cap07pdf

Nonogaki H, Bassel GW, Bewley JD. Germination - Still a mystery. Plant Science. 2010;179(6):574581. doi: doi.org/10.1016/j.plantsci.2010.02.010.

Novikova GV, Tournaire-Rouxb C, Sinkevicha IA, Lityagina SV, Maurel C, Obroucheva N. Vacuolar biogenesis and aquaporin expression at early germination of broad bean seeds. Plant Physiology and Biochemistry. 2014;82:123-132. doi: 10.1016/j. plaphy.2014.05.014.

Obroucheva NV, Lityagina SV, Novikova GV, Sin'kevich IA. Vacuolar status and water relations in embryonic axes of recalcitrant Aesculus hippocastanum seeds during stratification and early germination. AoB Plants. 2012;2012:pls008. doi: 10.1093/aobpla/pls008.

Preston GM, Carroll TP, Guggino WB, Agre P. Appearance of water channels in Xenopus oocytes expressing red cell CHIP28 protein. Science. 1992;256(5055):385-387. doi: 10.1126/ science. 256.5055 .385 .

Qi S, Wang R, Chaitra GKM, Torres J, Hu X, Fane AG. Aquaporin-based biomimetic reverse osmosis membranes: Stability and long term performance. Journal of Membrane Science. 2016;508:94-103. doi: doi.org/10.1016/j.memsci.2016.02.013.

R Development Core Team. R: a language and environment for statistical computing. $\mathrm{R}$ Foundation for Statistical Computing, Vienna; 2011. [accessed: 12 October 2017]. Available from: http://www.R-project.org.

\section{Revista Árvore 2019;43(6):e430601}


Regazzi AJ. Teste para verificar a identidade de modelos de regressão e a igualdade de alguns parâmetros num modelo polinomial ortogonal. Revista Ceres. 1993;40(228):176-195. [accessed: 14 February 2018]. Available from: http:// wwwceresufvbr/ojs/indexphp/ceres/article/ download/2190/226

Savage DF, Stroud RM. Structural basis of aquaporin inhibition by mercury. Journal of Molecular Biology. 2007;368(3):607-617. doi: 10.1016/j.jmb.2007.02.070.

Sereda F, Reissmann CB, Marques R, Britez RM. Aspectos nutricionais de sementes e plântulas de guapuruvu desenvolvidas em dois substratos. Scientia Agraria. 2008;9(4):579-585. doi: http://dx.doi. org/10.5380/rsa.v9i4.13257

Steinbrecher T, Leubner-Metzger G. The biomechanics of seed germination. Journal of Experimental Botany. 2017;68(4):765-783. doi:
$10.1093 / \mathrm{jxb} / \mathrm{erw} 428$.

Štolfa I, Pfeiffer TŽ, Špoljarić D, Teklić T, Lončarić Z. Heavy Metal-Induced Oxidative Stress in Plants: Response of the Antioxidative System. In. Gupta DK, Palma JM, Corpas FJ (eds), Reactive Oxygen Species and Oxidative Damage in Plants Under Stress. Cham: Springer; 2015. doi:https://doi. org/10.1007/978-3-319-20421-5_6.

Tyerman SD, Bohnert HJ, Maurel C, Steudle E, Smith JAC. Plant aquaporins: their molecular biology, biophysics and significance for plant water relations. Journal of Experimental Botany. 1999;50:1055-1071.doi: https://doi.org/10.1007/9783-319-20421-5 6

Willigen CV, Postaire O, Tournaire-Roux C, Boursiac Y, Maurel, C. Expression and inhibition of aquaporins in germinating Arabidopsis seeds. Plant and Cell Physiology. 2006;47(9):1241-1250. doi: 10.1093/pcp/pcj094. 